\title{
Authentic Learning Berbasis Inquiry dalam Program STEM terhadap Literasi Saintifik Siswa Berdasarkan Tingkatan Kemampuan Pemecahan Masalah Siswa
}

\begin{tabular}{|c|c|}
\hline & $\begin{array}{l}\text { Idawati }^{1}, \text { Muhardjito }^{1} \text {, Lia Yuliati }{ }^{1} \\
{ }^{1} \text { Pendidikan Fisika-Universitas Negeri Malang }\end{array}$ \\
\hline INFO ARTIKEL & ABSTRAK \\
\hline $\begin{array}{l}\text { Riwayat Artikel: } \\
\text { Diterima: 28-05-2019 } \\
\text { Disetujui: 14-08-2019 }\end{array}$ & \multirow{2}{*}{$\begin{array}{l}\text { Abstract: Scientific literacy is one of the basic skills that must be possessed in the XXI } \\
\text { century. The } 2015 \text { PISA results show that scientific, mathematical, and reading literacy } \\
\text { in Indonesian students is ranked 64th out of } 72 \text { countries and it is still relatively low. In } \\
\text { the process of learning physics students are very weak in applying physics concepts } \\
\text { learned because learning is less stressed on problem solving. The purpose of this study } \\
\text { was to determine the effect of students 'problem solving abilities in inquiry-based } \\
\text { authentic learning in the STEM program on students' scientific literacy. This study was a } \\
\text { quasi-experimental study using a } 2 \text { x } 2 \text { factorial design. Data collection was carried out by } \\
\text { tests conducted before and after the study in the experimental class and the control class. } \\
\text { Test results data were analyzed by different tests. The results showed that scientific } \\
\text { literacy of students who have high problem-solving skills is higher when learning with } \\
\text { authentic inquiry-based learning approaches in STEM programs than conventional, while } \\
\text { scientific literacy of students who have low problem-solving abilities is higher when } \\
\text { learning with authentic inquiry-based learning approaches in STEM programs rather than } \\
\text { conventional. }\end{array}$} \\
\hline $\begin{array}{l}\text { Kata kunci: } \\
\text { authentic learning; } \\
\text { inquiry; } \\
\text { STEM program; } \\
\text { scientific literacy; } \\
\text { program STEM; } \\
\text { literasi saintifik }\end{array}$ & \\
\hline & $\begin{array}{l}\text { Abstrak: Literasi saintifik merupakan salah satu keterampilan dasar di abad XXI yang } \\
\text { harus dimiliki peserta didik. Pada proses pembelajaran fisika, peserta didik sangat lemah } \\
\text { dalam mengaplikasikan konsep fisika yang dipelajari karena pembelajaran kurang } \\
\text { menekankan pada pemecahan masalah. Penelitian ini bertujuan mengetahui pengaruh } \\
\text { kemampuan pemecahan masalah peserta didik dalam pembelajaran authentic learning } \\
\text { berbasis inquiry dalam program STEM pada literasi saintifik peserta didik. Penelitian ini } \\
\text { merupakan penelitian quasi eksperiment dengan menggunakan rancangan penelitian } \\
\text { faktorial 2x2. Pengumpulan data dilakukan dengan tes yang dilakukan sebelum dan } \\
\text { sesudah penelitian pada kelas eksperimen dan kelas kontrol. Data hasil tes dianalisis } \\
\text { dengan uji lanjut Tukey. Hasil penelitian menunjukkan literasi sainstifik peserta didik } \\
\text { yang memiliki kemampuan pemecahan masalah tinggi, lebih tinggi jika belajar dengan } \\
\text { pendekatan authentic learning berbasis inquiry dalam program STEM daripada yang } \\
\text { belajar dengan cara konvensional dan sedangkan literasi saintifik peserta didik yang } \\
\text { memiliki kemampuan pemecahan masalah rendah, lebih tinggi jika belajar dengan } \\
\text { pendekatan authentic learning berbasis inquiry dalam program STEM daripada yang } \\
\text { belajar dengan cara konvensional. }\end{array}$ \\
\hline
\end{tabular}

Alamat Korespondensi:

Idawati

Pendidikan Fisika

Universitas Negeri Malang

Jalan Semarang 5 Malang

E-mail: Idawati@um.ac.id

Literasi saintifik merupakan salah satu keterampilan utama yang harus dikuasai peserta didik untuk mencapai tujuan pendidikan saintifik (Gucluer \& Kesercioglu, 2012). Literasi saintifik sangat penting untuk mempersiapkan peserta didik menghadapi tantangan di masa depan (Bay, Vickers, Mora, Sloboda, \& Morton, 2017). Peserta didik yang memiliki literasi saintifik bersedia untuk terlibat dalam penalaran wacana tentang ilmu pengetahuan dan teknologi (Abidin, Mulyati, \& Yunansah, 2017). Aspek literasi sains terdiri dari konteks, pengetahuan, kompetensi, dan sikap (Abidin et al., 2017; Afriana, Permanasari, \& Fitriani, 2016; Bay et al., 2017). Aspek konteks mencakup keterlibatan sains pada isu-isu terbaru; aspek pengetahuan mencakup area pemahaman terhadap fakta-fakta, konsep, dan teori; aspek sikap, meliputi bagaimana respon terhadap isu sains; aspek kompetensi mencakup bagaimana menjelaskan fenomena ilmiah, mengevaluasi dan mendesain penelitian ilmiah, menafsirkan data dan bukti ilmiah sebagai dasar mengevaluasi data, klaim, dan argumen dalam berbagai representasi dan menarik kesimpulan ilmiah yang sesuai (Abidin et al., 2017; OECD, 2016). 
Fisika sebagai bagian dari sains yang merupakan bidang ilmu yang memiliki kajian fenomena alam dan interaksinya (Sarojo, 2013). Sebagai ilmu yang mengkaji alam dan interaksinya, pembelajaran fisika harus bisa secara konsisten menggali keterampilan-keterampilan yang dibutuhkan di abad XXI. Pembelajaran fisika harus dapat melatih peserta didik dalam mengamati, menganalisis, berhipotesis, memprediksi, merangkai, mengukur, menarik kesimpulan, memecahkan masalah, dan dapat mengaplikasikan konsep fisika yang dipelajari dalam kehidupan sehari-hari (Datur, Yuliati, \& Mufti, 2017; Sungkawan \& Motlan, 2013; Sutopo, 2015).

Salah satu keterampilan utama yang diperlukan dalam belajar fisika adalah pemecahan masalah. Pengalaman belajar pada mata pelajaran fisika diharapkan mampu menanamkan keaslian dalam setiap tugas dan pembelajaran untuk memastikan bahwa peserta didik mampu mengembangkan keterampilan memecahkan masalah dan keyakinan dalam kemampuan belajar peserta didik (Nicaise, Gibney, \& Crane, 2000). Peserta didik dengan kemampuan pemecahan masalah yang baik dapat memecahkan masalah yang kompleks dalam kehidupan sehari-hari (Crebert, Patrick, \& Cragnolini, 2011). Melalui kemampuan pemecahan masalah peserta didik mampu mengaplikasikan keterampilan dan pengetahuan dalam dunia nyata.

Pada proses pembelajaran, peserta didik kurang mengaplikasikan konsep fisika. Salah satu konsep fisika yang jarang diaplikasikan yaitu konsep fluida statis. Kesulitan yang dihadapi peserta didik dalam memahami konsep tekanan disebabkan karena tidak memahami makna $h$ (kedalaman) dalam konsep tekanan hidrostatis (Goszweski, Moyer, Bazan, \& Wagner, 2012). Peserta didik memahami makna $h$ sebagai ketinggian karena pada konsep fisika lain $h$ merupakan besaran ketinggian. Akibat dari adanya miskonsepsi ini membuat peserta didik jarang mengaplikasikan konsep fisika dalam kehidupan sehari-hari yang membuat literasi saintifik peserta didik rendah. Maka, diperlukan metode pembelajaran yang bisa mengontekstualkan pengetahuan dengan alam semesta pada bidang yang sedang dipelajari.

Authentic learning merupakan pembelajaran yang dirancang untuk menghubungkan apa yang dipelajari peserta didik dengan masalah-masalah dalam keseharian. Pembelajaran autentik mencakup kegiatan mengasimilasikan pengetahuan baru ke dalam struktur skemata pengetahuan awal peserta didik, konsep yang diajarkan secara berulang dan teratur serta dikaitkan dengan informasi baru, dan konsep yang dipelajari selalu menjadi bagian yang lebih besar dari "kegiatan pembelajaran" yang langsung terkait dalam pikiran peserta didik dengan setting, kegiatan, dan lingkungan sosial (Lombardi, 2007). Authentic learning didukung oleh pengalaman belajar berbasis penyelidikan (inquiry) melalui kegiatan observasi dan eksperimen (Lombardi, 2007). Authentic learning dan inquiry merupakan kesatuan dimana data yang dikumpulkan dan diperoleh melalui observasi dan eksperimen, baik laboratorium atau lapangan, mengarah pada pengembangan model dan eksplanatoris hipotesis yang memungkinkan prediksi suatu kejadian pada kehidupan sehari-hari. Prediksi ini merupakan ide-ide baru dibangun berdasarkan pengetahuan sebelumnya, menggali bagaimana pengetahuan tersebut diperoleh, mendesain dan mengevaluasi penyelidikan, dan menginterpretasikan data untuk menarik kesimpulan yang merupakan keterampilan dari literasi saintifik. Hal ini sejalan dengan penelitian (Gormally, Brickman, \& Lutz, 2012) menyatakan bahwa dengan menerapkan pembelajaran berbasis inquiry dapat meningkatkan literasi saintifik peserta didik (Gormally et al., 2012).

Tujuan penelitian ini adalah untuk mengetahui pengaruh kemampuan pemecahan masalah peserta didik dalam pembelajaran authentic learning berbasis inquiry dalam program STEM pada literasi sainstifik peserta didik. Sehingga, authentic learning berbasis inquiry diajarkan dengan menggunakan pendekatan STEM (Science, Technology, Engineering, and Mathematics). Pembelajaran STEM mengintegrasikan sains, teknologi, teknik, dan matematika dapat membekali kesuksesan abad XXI (Beers, 2011; Guzey, Moore, Harwell, \& Moreno, 2016). STEM diharapkan dapat menghasilkan peserta didik yang dapat mengembangkan kompetensi yang telah dimilikinya untuk mengaplikasikannya pada berbagai situasi dan permasalahan yang dihadapi di kehidupan sehari-hari dan menghadapi tantangan dan tuntutan perkembangan zaman (Mayasari, Kadarohman, \& Rusdiana, 2014; Widayoko, Latifah, \& Yuliati, 2018). STEM dapat berkembang apabila dikaitkan dengan lingkungan, sehingga terwujud pembelajaran dalam kehidupan sehari-hari (Subramaniam, et al., 2012). Melalui pendekatan STEM, peserta didik tidak hanya memahami konsep, tetapi lebih kepada bagaimana peserta didik mengaitkannya dalam kehidupan sehari-hari yang dapat meningkatkan literasi saintifik peserta didik (Afriana et al., 2016; Widayoko et al., 2018).

\section{METODE}

Penelitian ini berjenis penelitian kuantitatif dengan metode quasi eksperiment yang menggunakan rancangan penelitian faktorial 2 × 2. Rancangan ini menggunakan dua kelompok yang diambil secara random sebagai kelompok eksperimen dan kelompok kontrol. Penelitian ini dilakukan untuk melihat perbedaan literasi saintifik peserta didik yang dipelajari menggunakan authentic learning berbasis inquiry dalam program STEM sebagai kelas eksperimen dengan kelas kontrol yang hanya menggunakan model pembelajaran konvensional. Kelas eksperimen belajar dengan peneliti, sedangkan kelas kontrol belajar dengan guru fisika yang bertanggung jawab pada kelas tersebut. Rancangan penelitian faktorial 2 x 2 dapat dilihat pada gambar 1 (Gall, Gall, \& Borg, 2003). 


\begin{tabular}{|llll|}
\hline $\mathrm{O}_{1}$ & $\mathrm{X}_{1}$ & $\mathrm{Y}_{1}$ & $\mathrm{O}_{2}$ \\
$\mathrm{O}_{1}$ & $\mathrm{X}_{1}$ & $\mathrm{Y}_{2}$ & $\mathrm{O}_{2}$ \\
$\mathrm{O}_{1}$ & $\mathrm{X}_{2}$ & $\mathrm{Y}_{1}$ & $\mathrm{O}_{2}$ \\
$\mathrm{O}_{1}$ & $\mathrm{X}_{2}$ & $\mathrm{Y}_{2}$ & $\mathrm{O}_{2}$ \\
\hline
\end{tabular}

\section{Gambar 1. Rancangan Penelitian Quasi Eksperimen Faktorial 2 x 2}

Seluruh sampel dibedakan kedalam peserta didik yang memiliki kemampuan pemecahan masalah tinggi dan peserta didik yang memiliki kemampuan pemecahan masalah rendah (tabel 1).

Tabel 1. Pola Rancangan Penelitian Faktorial 2 x 2

\begin{tabular}{ccc}
\hline $\begin{array}{c}\text { Kemampuan } \\
\text { Pemecahan Masalah } \\
(B)\end{array}$ & \multicolumn{2}{c}{ Literasi Saintifik } \\
\cline { 2 - 3 } & $\begin{array}{c}\text { Authentic Learning berbasis Inquiry dalam program STEM } \\
\left(\mathrm{A}_{\mathbf{1}}\right)\end{array}$ & $\begin{array}{c}\text { Pembelajaran } \\
\text { konvensional } \\
\left(\mathbf{A}_{2}\right)\end{array}$ \\
\hline $\mathrm{B}_{1}$ Tinggi & $\mathrm{A}_{1} \mathrm{~B}_{1}$ & $\mathrm{~A}_{2} \mathrm{~B}_{1}$ \\
\hline $\mathrm{B}_{2}$ Rendah & $\mathrm{A}_{1} \mathrm{~B}_{2}$ & $\mathrm{~A}_{2} \mathrm{~B}_{2}$ \\
\hline
\end{tabular}

Sumber: (Gall et al., 2003)

Sampel yang dibutuhkan dalam penelitian ini terdiri dari enam kelas, yakni tiga kelas sebagai kelas eksperimen dan tiga kelas sebagai kelas kontrol. Pengambilan sampel dalam penelitian ini menggunakan teknik sampel jenuh yaitu teknik penentuan sampel yang menjadikan semua anggota populasi sebagai sampel. Untuk mengetahui sampel pada kelas eksperimen dan kelas kontrol maka dilakukan undian dari 6 kelas yang menjadi sampel. Undian yang dilakukan yaitu dengan cara arisan, dimana kelas yang mendapat gulungan kertas yang berisi tulisan "eksperimen" termasuk kelas eksperimen, sedangkan kelas yang mendapat gulungan kertas yang berisi tulisan "kontrol" termasuk kelas kontrol sehingga terpilih kelas X MIA 2, X MIA 3, X MIA 5 sebagai kelas eksperimen dan X MIA 1, X MIA 4, X MIA 6 sebagai kelas kontrol.

Pengambilan data dilakukan dengan tes. Hasil tes dilakukan uji prasayarat normalitas dan homogenitas untuk menentukan jenis statistik yang digunakan untuk uji hipotesis. Pengujian hipotesis bertujuan untuk mengetahui pengaruh pemberian perlakuan dengan penggunaan authentic learning dalam program STEM berbasis inquiry terhadap peningkatan literasi sains peserta didik. Pengujian hipotesis menggunakan ANAVA dua jalur dan dilanjutkan dengan uji Tukey karena jumlah data yang diuji sama.

\section{HASIL}

Data Kemampuan Pemecahan Masalah Awal

Pada awal penelitian kelas eksperimen dan kelas kontrol diberi tes kemampuan pemecahan masalah yang berbentuk essay untuk mengetahui tingkat pemecahan masalah peserta didik rendah atau tinggi. Hasil tes kemampuan pemecahan masalah awal dapat dilihat pada tabel 2 .

Tabel 2. Data Kemampuan Pemecahan Masalah

\begin{tabular}{ccc}
\hline Statistik & $\begin{array}{c}\text { Authentic Learning berbasis Inquiry } \\
\text { dalam Program STEM }\end{array}$ & Konvensional \\
\hline $\mathrm{n}$ & 87 & 87 \\
\hline $\mathrm{x}$ & 21,02 & 22,08 \\
\hline $\mathrm{s}$ & 4,95 & 4,06 \\
\hline $\mathrm{N}_{\mathrm{min}}$ & 10 & 10 \\
\hline $\mathrm{N}_{\mathrm{maks}}$ & 30 & 31 \\
\hline
\end{tabular}

Data Kemampuan Literasi Saintifik

Tes literasi saintifik peserta didik dilaksanakan setelah pembelajaran dilaksanakan. Tes dilaksanakan di semua kelas baik kelas eksperimen maupun kelas kontrol. Tes literasi saintifik berbentuk esai berjumlah empat soal yang sudah divalidasi. Waktu yang digunakan dalam mengerjakan soal tes adalah 90 menit. Hasil tes literasi saintifik dapat dilihat pada tabel 3 . 
Setelah mengetahui literasi saintifik peserta didik secara keseluruhan, kemudian dipilih literasi saintifik peserta didik yang masuk dalam kelompok pemecahan masalah tinggi dan rendah untuk masing-masing kelas kontrol maupun kelas eksperimen. Jadi peserta didik berkemampuan pemecahan masalah tinggi sebanyak 29 dan peserta didik berkemampuan pemecahan masalah rendah sebanyak 29. Data literasi saintifik tersebut akan digunakan sebagai bahan untuk analisis uji hipotesis dengan analisis varians (ANAVA) dua jalur.

Tabel 3. Nilai Literasi Saintifik

\begin{tabular}{ccc}
\hline Statistik & $\begin{array}{c}\text { Authentic Learning berbasis Inquiry } \\
\text { dalam Program STEM }\end{array}$ & Konvensional \\
\hline $\mathrm{n}$ & 87 & 87 \\
\hline $\mathrm{x}$ & 40,28 & 37,69 \\
\hline $\mathrm{s}$ & 3,62 & 2,98 \\
\hline $\mathrm{N}_{\min }$ & 31 & 31 \\
\hline $\mathrm{N}_{\mathrm{maks}}$ & 47 & 43 \\
\hline
\end{tabular}

Uji prasyarat (normalitas dan homogenitas) dilakukan sebelum dilakukan uji hipotesis. Data yang digunakan adalah data nilai literasi saintifik peserta didik. Uji normalitas dilakukan menggunakan uji Lilliefors sedangkan uji homogenitas dilakukan dengan uji Bartlett yang hasil dari uji prasyarat dapat dilihat pada tabel 4 dan 5. Uji hipotesis manggunakan analisis varians dua Jalur. Hasil analisis varians dua jalur dapat dilihat pada tabel 6.

Tabel 4. Hasil Uji Normalitas

\begin{tabular}{ccc}
\hline \multirow{2}{*}{ Statistik } & \multicolumn{2}{c}{ Kelas } \\
\cline { 2 - 3 } & $\begin{array}{c}\text { Authentic Learning berbasis Inquiry } \\
\text { dalam program STEM }\end{array}$ & Konvensional \\
\hline $\mathbf{N}$ & 87 & 87 \\
\hline $\mathbf{L}_{\text {hitung }}$ & 0,065 & 0,074 \\
\hline $\mathbf{L}_{\text {tabel }}$ & 0,094 & 0,094 \\
\hline Kesimpulan & L $_{\text {hitung }}<\mathrm{L}_{\text {tabel }}$ maka, data terdistribusi Normal & L $_{\text {hitung }}<\mathrm{L}_{\text {tabel }}$ maka, data terdistribusi Normal \\
\hline
\end{tabular}

Tabel 5. Hasil Uji Homogenitas Varians Data

\begin{tabular}{ccc}
\hline$\chi_{\text {hitung }}^{2}$ & $\chi_{\text {tabel }}^{2}$ & Keterangan \\
\hline 0,6476 & 3,841 & $\chi_{\text {hitung }}^{2} \leq \chi_{\text {tabel }}^{2}$, maka data Homogen \\
\hline
\end{tabular}

Tabel 6. Hasil Analisis Varians Dua Jalur

\begin{tabular}{lccccc}
\hline \multicolumn{1}{c}{ Varians } & db & JK & RK & F Hitung $_{\text {Fabel }}$ & F $_{\text {Tabis (b) }}$ \\
\hline Kelompok Bariom (k) & 1 & 186,28 & 186,28 & 18,26 & 3,93 \\
\hline Kelompok Kolom & 1 & 45,94 & 45,94 & 4,50 & 3,93 \\
\hline Interaksi (bxk) & 1 & 41,04 & 41,04 & 4,02 & 3,93 \\
\hline Dalam & 112 & 1142,34 & 10,20 & & \\
\hline Total & 115 & 1415,61 & & & \\
\hline
\end{tabular}

\section{PEMBAHASAN}

Authentic learning merupakan pembelajaran yang dirancang untuk menghubungkan apa yang diajarkan peserta didik dengan masalah-masalah dalam keseharian dengan pembelajaran berbasis penyelidikan (inquiry) melalui kegiatan observasi dan eksperimen (Lombardi, 2007). Pada penelitian ini authentic learning dipadukan dengan STEM. Konteks inquiry pada authentic learning dipadukan pada aspek STEM yaitu sains, teknologi, engineering, dan matematika. Perpaduan authentic learning dengan STEM digunakan untuk meningkatkan literasi saintifik peserta didik. Literasi saintifik merupakan salah satu keterampilan penting untuk mempersiapkan peserta didik menghadapi tantangan di masa depan. Peserta didik yang memiliki literasi saintifik bersedia untuk terlibat dalam penalaran wacana tentang ilmu pengetahuan dan teknologi (Abidin, et al. , 2017). Fisika sebagai ilmu yang mengkaji alam dan interaksinya, pembelajaran fisika harus bisa secara konsisten menggali keterampilan-keterampilan yang dibutuhkan di abad XXI salah satunya melalui pemecahan masalah. 
Pada penelitian ini, pemecahan masalah dibedakan menjadi tiga kategori, yaitu pemecahan masalah rendah, sedang, dan tinggi. Namun, hanya pemecahan masalah tinggi dan rendah saja yang digunakan untuk mengetahui pengaruhnya terhadap literasi saintifik. Dari hasil analisis data disimpulkan bahwa pemecahan masalah yang dimiliki peserta didik berpengaruh terhadap literasi saintifik peserta didik. Peserta didik yang memiliki kemampuan pemecahan masalah tinggi, ternyata memiliki literasi yang lebih tinggi dibandingkan dengan peserta didik yang memiliki pemecahan masalah rendah. Hal ini sejalan dengan pernyataan (Nicaise, 2000) menyatakan bahwa pengalaman belajar dalam memecahkan masalah dapat membantunya menangani permasalahan hidup. Selain itu, peserta didik dengan kemampuan pemecahan masalah yang baik dapat memecahkan masalah yang kompleks dalam kehidupan sehari-hari (Crebert, et al., 2011).

Hipotesis penelitian terkait dengan adanya interaksi antara authentic learning berbasis inquiry dalam program STEM dan kemampuan pemecahan masalah terhadap literasi saintifik peserta didik". Pada tabel 6 terlihat bahwa literasi saintifik peserta didik dipengaruhi oleh pendekatan authentic learning berbasis inquiry dalam program STEM, karena nilai $\mathrm{F}_{\text {hitung }}>\mathrm{F}_{\text {tabel }}$ yaitu 18,26 > 3,93. Literasi saintifik tidak hanya dipengaruhi oleh pendekatan authentic learning berbasis inquiry dalam program STEM tetapi juga dipengaruhi oleh kemampuan pemecahan masalah peserta didik. Hal ini sejalan dengan penelitian (Gormally et al., 2012) yang menyatakan bahwa dengan menerapkan pembelajaran berbasis inquiry dapat meningkatkan literasi saintifik peserta didik (Gormally et al.,2012).

Selain itu, perbedaan kemampuan pemecahan masalah tinggi maupun rendah juga menyebabkan perbedaan nilai literasi saintifik peserta didik. Hasil analisis data untuk antar baris didapatkan nilai $F_{\text {hitung }}$ sebesar 4,50 dan $F_{\text {tabel }}$ sebesar 3,93, maka dapat disimpulkan terdapat perbedaan kemampuan pemecahan masalah peserta didik yang belajar dengan pendekatan authentic learning berbasis inquiry dalam program STEM dan cara konvensional, karena nilai $F_{\text {hitung }}>F_{\text {tabel }}$ yaitu 4,50 $>3,93$. Jika terdapat perbedaan maka dilanjutkan dengan uji lanjut Tukey untuk mengetahui interaksi interaksi antara authentic learning berbasis inquiry dalam program STEM dan kemampuan pemecahan masalah terhadap literasi saintifik peserta didik. Hasil uji Tukey

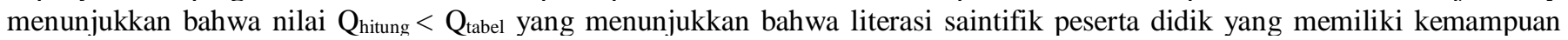
pemecahan masalah tinggi, lebih tinggi jika belajar dengan pendekatan authentic learning berbasis inquiry dalam program STEM daripada yang belajar dengan cara konvensional. Literasi saintifik peserta didik yang memiliki kemampuan pemecahan masalah rendah, lebih tinggi jika belajar dengan pendekatan authentic learning berbasis inquiry dalam program STEM daripada yang belajar dengan cara konvensional.

\section{SIMPULAN}

Peserta didik dengan pemecahan masalah tinggi pada kelas yang menggunakan pendekatan authentic learning berbasis inquiry dalam program STEM memiliki literasi saintifik lebih tinggi daripada kelas kontrol dengan pembelajaran konvensional, dan peserta didik dengan pemecahan masalah rendah dengan pendekatan authentic learning berbasis inquiry dalam program STEM, memiliki literasi yang lebih tinggi jika dibandingkan dengan peserta didik pada kelas konvensional. Hal ini menunjukkan bahwa kemampuan pemecahan masalah memengaruhi literasi saintifik peserta didik begitu juga dengan penggunaan pendekatan authentic learning berbasis inquiry dalam program STEM. Saran yang bisa peneliti berikan untuk penelitian selanjutnya adalah menyertakan variasi pemecahan masalah kategori sedang sehingga memudahkan pola hubungan antara pemecahan masalah dengan penggunaan model serta pengaruhnya terhadap literasi saintifik.

\section{DAFTAR RUJUKAN}

Abidin, Y., Mulyati, T., \& Yunansah, H. (2017). Pembelajaran Literasi. Jakarta: Bumi Aksara.

Afriana, J., Permanasari, A., \& Fitriani, A. (2016). Penerapan Project Based Learning Terintegrasi STEM untuk Meningkatkan Literasi Sains Siswa Ditinjau dari Gender. Jurnal Inovasi Pendidikan IPA, 2(2), 202-212. https://doi.org/10.21831/jipi.v2i2.8561

Bay, J., Vickers, M., Mora, H., Sloboda, D., \& Morton, S. (2017). Adolescents as Agents of Healthful Change Through Scientific Literacy Development: A School-University Partnership Program In New Zealand. International Journal of STEM Education, 4(1).

Crebert, G., Patrick, C., \& Cragnolini, V. (2011). Problem Solving Skills Toolkit. Griffith University.

Datur, I., Yuliati, L., \& Mufti, N. (2017). Kemampuan Pemecahan Masalah Materi Fluida Statis melalui Pembelajaran Berbasis Masalah Berbantuan Thinking Maps. Jurnal Inspirasi Pendidikan, 2(7), 118-127.

Gall, M., Gall, J., \& Borg, W. (2003). Educational Research, An Introduction (7th edition). Boston: Pearson Education, Inc.

Gormally, C., Brickman, P., \& Lutz, M. (2012). Developing a Test of Scientific Literacy Skills (TOSLS): Measuring Undergraduates Evaluation of Scientific Information and Arguments. CBE-Life Sciences Education, 11, 364-377. https://doi.org/10.1187/cbe.12-03-0026

Goszweski, M., Moyer, A., Bazan, Z., \& Wagner, D. (2012). Exploring Student Difficulties with Pressure in a Fluid. PERC Proceedings. the American Association of Physics Teachers Under a Creative Commons Attribution. 
Gucluer, E., \& Kesercioglu, T. (2012). The Effect of Using Activities Improving Scientific Literacy on Students' Achievement in Science and Technology Lesson. International Online Journal of Primary Education, 1(1), 3-10.

Guzey, S. S., Moore, T. J., Harwell, M., \& Moreno, M. (2016). STEM Integration in Middle School Life Science: Student Learning and Attitudes. Journal of Science Education and Technology, 25(4), 550-560. https://doi.org/10.1007/s10956016-9612-X

Lombardi, M. (2007). Authentic Learning for The 21st Century: An Overview. Educause Learning Initiative : Advancing Learning Through IT Innovation.

Mayasari, T., Kadarohman, A., \& Rusdiana, D. (2014). Pengaruh Pembelajaran Terintegrasi Science, Technology, Engineering, and Mathematics (STEM) Pada Hasil Belajar Peserta Didik: Studi Meta Analisis. Prosiding Semnas Pensa VI "Peran Literasi Sains", 371-377.

Nicaise, I. (2000). The Right to Learn: Educational Strategies for Socially Excluded Youth in Europe. Policy Press.

Nicaise, N., Gibney, G., \& Crane, C. (2000). Toward an Understanding of Authentic Learning: Student Perceptions of an Authentic Classroom. Journal of Science Education and Technology, 9(1).

OECD. (2016). PISA 2015 Assessment and Analytical Framework Science, Reading, Mathematic, Financial Literacy and Collaborative Problem Solving (Revisied E). Paris: OECD Publishing.

Sarojo, G. A. (2013). Seri Fisika Dasar Mekanika Edisi 5. Jakarta: Penerbit Salemba Teknika.

Subramaniam, M. M., Ahn, J., Fleischmann, K. R., \& Druin, A. (2012). Reimagining the Role of School Libraries in STEM Education: Creating Hybrid Spaces for Exploration. The Library Quarterly, 82(2), 161-182.

Sungkawan, R., \& Motlan. (2013). Analisis Penguasaan Konsep Awal Fisika pada Pembelajaran menggunakan Model Advance Organizer Berbasis Eksperimen terhadap Hasil Belajar Fisika. Jurnal Pendidikan Fisika, 2(1), 73-80.

Sutopo, S. (2015). Pembelajaran Kinematika Berbasis Diagram Gerak: Cara Baru dalam Pengajaran Kinematika. Seminar Nasional Penelitian Universitas Negeri Yogyakarta, (June 2012), 11.

Widayoko, A., Latifah, E., \& Yuliati, L. (2018). Peningkatan Kompetensi Literasi Saintifik Siswa SMA dengan Bahan Ajar Terintegrasi STEM pada Materi Impuls dan Momentum. Jurnal Pendidikan: Teori, Penelitian, \& Pengembangan, 3(11), $1463-1467$. 